\title{
Migration of Youths in Russia: Impact on Sex-age Structures
}

\section{llya Kashnitsky}

\author{
National Research University Higher School of Economics \\ Institute of Demography, Moscow \\ Email: ilya.kashnitsky@gmail.com
}

\section{Doi:10.5901/mjss.2013.v4n10p358}

\begin{abstract}
Abstrsct
Migration (especially internal) changes sex-age structures substantially both in donor and host areas. As long as migration involves mainly young people, their relocation to the big cities (mainly regional centers) accelerates population ageing in peripheral areas and thus depopulation. Ageing is particularly fast in the Russian hinterland. Here you can find areas with the median age of population reaching the edge of 50 years. The cohort research on youth's migration to the centers on the last two Russian census data shows that up to $70 \%$ of school graduates leave the regional periphery for good. At the end of the article there is an author's method which presents the attempt to estimate the trend in regional center's migration attractiveness for the youths.
\end{abstract}

Keywords: Youth migration, periphery depopulation, center-peripheral population dynamics, cohort migration studies, method of shifting ages.

\section{Introduction}

In the face of depopulation (Russian reality of the last decades) migration becomes the key factor influencing the demographic structures. According to the idea of the Third Demographic Transition migration's impact on the dynamics of the population is growing significantly in the most demographically developed countries (Coleman 2006). This tendency became clear on the international level only in the last several decades when, after the Second World War, the developed countries experienced a great inflow of international migrants (Fassmann, Münz 1992; Massey, Arango et. all 1993). But on the internal level of migration researches the significance of migration impact on population dynamics was noticed much earlier (Ravenstein 1885, 1889; Hicks 1932; Price 1948; Lee 1966; Greenwood 1975; Frey 1995; Moiseenko 2004). But the empirical verification of the theoretical constructions came much later and firstly on the international level. It's easier to control and register the movements over the countries' borders.

The research on migration in Russia has its own historically determined features. One of the most peculiar is that in the USSR the current migration record was declared as the main source of information about spatial mobility of the population. The accuracy of the current record was the reverse side of extremely severe rules of the registration in the USSR. After the fall of the USSR this system was shaken to the core. The liberalization of the rules of tabulation by place of residence in Russia caused a lot of problems in migration statistics (Chudinovskikh 2005). And the most problematic group proved to be the youths, especially the "student" ages. That's why we are focusing our biggest part of attention on this particular age group in this paper.

The research on Russian migration using the Census data is important not only because the current migration record can't provide us with the precise information (apart from distorting the age-sex proportions of the migration flows). The comparison of two main sources of migration statistics brings us new valuable information. But the main idea of using the data from the last two Censuses is about analyzing spatial mobility of the population on intraregional level. Only Census data allows us to operate in this scale. The intraregional movements change the demographic structures most dramatically. The research for the previous period between two Censuses in Russia (1989-2002) showed that up to 40 per cent of school graduates leave regional periphery in the search of better opportunities (Mkrtchan 2012). Our research demonstrates that the migration situation of Russian hinterland is becoming more and more negative.

\section{The selectiveness of migration.}

Migration is the lot of young. This thesis is very well known. The selectiveness of migration was noted even in 
Ravestein's "Lows of migration" (Revenstein 1885, 1889). The term of "differential mobility" was introduced by Dorothy Thomas (Thomas 1938).

The key role of the youth's in spatial mobility is invariable. Even the Russian current migration record shows it. In our research we've chosen five key regions for the intraregional migration studying: Altai Krai, Kostromskaya oblast', Kurskaya oblast', Rostovskaya oblast' and Bashkortostan Republic. The age profile of intraregional migration "caught" by current migration record in these regions is odd (Figure 1). For some reason (surely the one mentioned above) there is a great difference in the young ages. The peak for Kurskaya oblast' and Bashkortostan Republic is precisely at the age of 18. Thou for the rest of the regions this maximum is not visible. Our hypothesis states that here we are seeing the problem of current migration record.

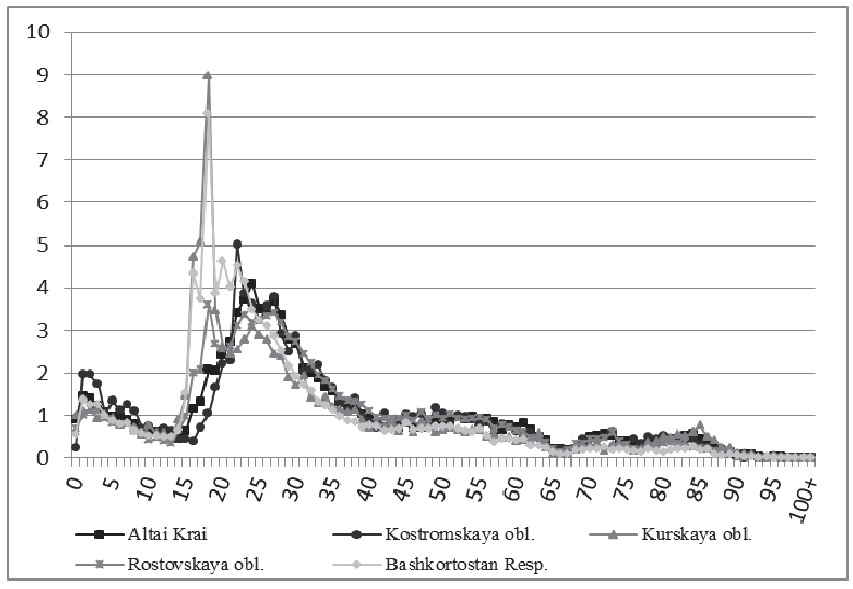

Figure 1. Age specific profiles of intraregional migration (inflow, age group share in the total number of migrants). Source: Rosstat, current migration record, 2010.

\section{Spatial differentiation of demographic structures as the consequence of internal migration.}

Census could be seen as an X-ray image of the population which we may use for "diagnosis". The demographic structures, which we can analyze with the Census data, demonstrate the imprint of the whole number of demographic processes experienced by the population. And the role of migration becomes crucial at the end of the Demographic Transition.

Center-peripheral migrations (accumulation of the population in the centers of attraction - mainly regional centers) in not a new phenomenon for Russia. The whole period of urbanization may be considered from this point of view. But in the face of depopulation this kind of spatial mobility accelerates the ageing and "slow extinction" of the peripheral population. The outflow of the young deprives Russian hinterland of the sustainable demographic development.

We can clearly see the result of the process on the maps build on Census 2010 data (see Appendix 1-8). These maps reflect some demographic features of the population formed by the time of the Census. The maps are built on the level of municipal districts (2343 in Russia). This scale gives us the opportunity to see the intraregional differences.

Firstly, let's have a look on the maps of the mean (Appendix 1) and the median (Appendix 2) age of Russian population. The indicators are quite similar but there is still a difference. The mean age is an arithmetical mean of the ages of all people. The median age divides the population in halves: one half is younger than the median age, the other is older. We prefer the median age because it responds dynamically to the changes in the demographic structures.

The rapid glance on the map of the median age of Russian population indicates the spatial differentiation of the modes of reproduction. The green (young) regions of The Northern Caucasus and The Southern Siberia are far from the end of the Demographic Transition. High fertility (the rudiment of the traditional mode of reproduction) responses for the great share of children in the age structure. High level of mortality keeps the share of old people insignificantly small. In the result we have very low median age (Figure 2). 


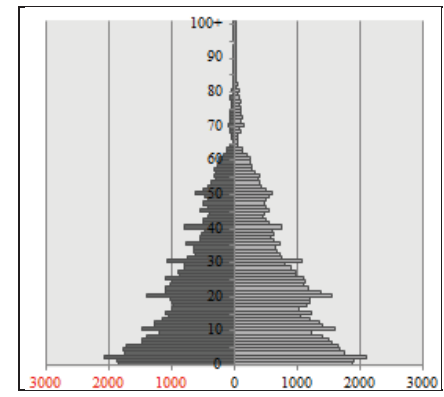

Figure 2. The demographic structure of the Kurchaloevskiy municipal district, Dagestan Republic. Median age: 20 years.

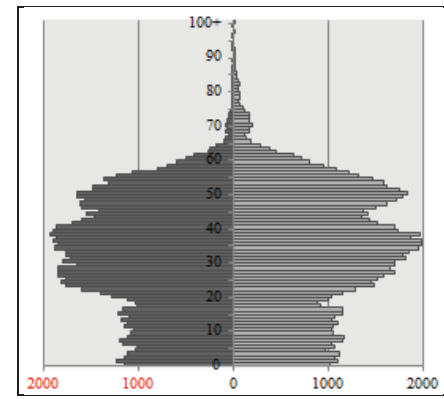

Figure 3. The demographic structure of Norilsk, Krasnoyarskiy Krai. Median age: 33,7 years.

The Far North regions (green on the map) have another story of "young" population formation. USSR started to populate these land forcefully in 1970-s. The migrants (enormously numerous compared to the aborigines) haven't become old yet. That's why the top of the sex-age pyramid is so shrunken (Figure 3). The other factor which deforms the pyramid is the outflow of pensioners to the warm regions of the country.

We started with these cases deliberately. Further they will interest us much less than the center-peripheral movements in the most populated parts of Russia. Here lies our biggest interest and here we consider the main goal of the research.

The regional centers are clearly visible on every our map (Appendix 1-8). The median age of the population here is much lower than in the hinterland. And in this we see the unmistakable proof of the center-periphery migration significance. Migrants, who are much younger than the locals due to the mentioned selectiveness of migration, contribute largely to the reduction of the median age of migration attractive center.

The impact of migration comes distinctly from the Table 1 . With the growth of territory's attractiveness the share of the youths (6) grows, gender disproportion (1) rises such as the median age (2), (3), (4), the burden on the working age population (5) increases. The distinction is not clear only between the groups with the number of the population "More than $250 \mathrm{~K}$ " and "More than $100 \mathrm{~K}$ ". The "Closed areas" have their own specifics.

Table 1. Russian municipal districts grouping by some demographic features of the population. * The groups are sorted by the hypothetical attractiveness (except "Closed areas").

\begin{tabular}{|c|c|c|c|c|c|c|}
\hline \multirow{3}{*}{ Group of territories* } & \multicolumn{6}{|c|}{ Mean value } \\
\hline & \multirow[b]{2}{*}{$\begin{array}{c}\text { Women per } \\
1000 \text { men } \\
\text { (1) }\end{array}$} & \multicolumn{3}{|c|}{ Median age } & \multirow{2}{*}{$\begin{array}{l}\text { Burden on the } \\
\text { working age } \\
\text { population } \\
\text { (5) }\end{array}$} & \multirow{2}{*}{$\begin{array}{c}\text { The share of } \\
\text { the young } \\
(16-29 \text { years } \\
\text { (6) }\end{array}$} \\
\hline & & $\begin{array}{c}\text { The whole } \\
\text { population } \\
\text { (2) }\end{array}$ & $\begin{array}{c}\text { Men } \\
(3)\end{array}$ & $\begin{array}{c}\text { Women } \\
\text { (4) }\end{array}$ & & \\
\hline Regional centers & 1218 & 36,3 & 33,6 & 39,1 & 57 & 24,5 \\
\hline More than $250 \mathrm{~K}$ & 1169 & 37,6 & 34,8 & 40,5 & 58 & 22,1 \\
\hline More than $100 \mathrm{~K}$ & 1160 & 37,7 & 34,7 & 40,7 & 64 & 21,6 \\
\hline
\end{tabular}




\begin{tabular}{ccccccc} 
Towns $(<100 \mathrm{~K})$ & 1140 & 37,6 & 34,7 & 40,6 & 64 & 20,7 \\
Municipal districts & 1118 & 39,7 & 36,7 & 42,6 & 70 & 19,1 \\
Closed areas & 982 & 33,7 & 30,7 & 37,4 & 50 & 26,7 \\
\cline { 2 - 6 } RUSSIA & $\mathbf{1 1 2 5}$ & $\mathbf{3 9 , 0}$ & $\mathbf{3 6 , 0}$ & $\mathbf{4 2 , 0}$ & $\mathbf{6 7 , 8}$ & $\mathbf{1 9 , 8}$ \\
\hline
\end{tabular}

Source: Census 2010 data.

The median age of male and female population maps (Appendix 3,4) comparison gives us the horrible picture of male's exciding mortality in Russia. When the male's map is mainly green (young population), the female's is red. And here is the rare case for our maps when green is not so good. The same picture is shown on the next map (Appendix 5) - the sex ratio. This indicator doesn't spotlight the regional centers because women are more active in the internal migration (Ravenstein 1889). At the same time center-peripheral migration and forthcoming depopulation form the "grannies land" in the most depressive parts of the hinterland. A bit clearer the regional centers are on the similar map for the "student" age group - 18-22 years (Appendix 6). Here the role of mortality is still tiny. Our estimates show that they are less than $1 \%$ for the cohorts during the last period between Censuses.

Let's have a look on the most characteristic samples of the center-peripheral youth's migration impact on demographic structures.

The demographic structure of Tomsk (Figure 4) is quite similar to the Russian one. The key distinction is the "skirt" in the "student" ages. Tomsk is a very important learning center.

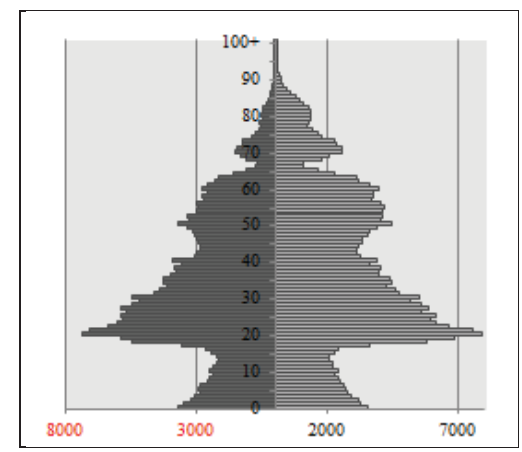

Figure 4. The demographic structure of Tomsk, Tomskaya oblast'. Median age: 32,9 years.

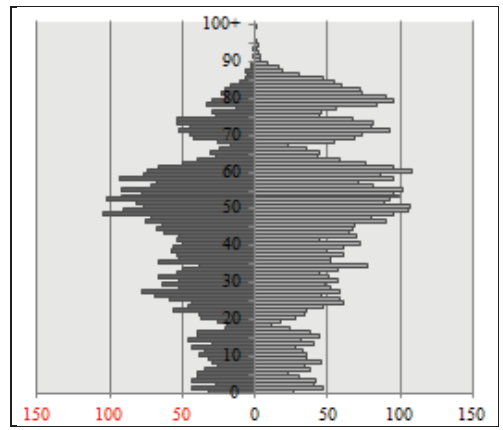

Figure 5. The demographic structure of Pustoshkinskiy municipal district, Pskovskaya oblast'. Median age: 48,8 years (51,4 for women!).

The opposite picture is typical for the most depressive hinterland districts. Look at the demographic structure of Pustoshkinskiy municipal district in Pskov region. We can see the result of youth's flee for the decades. The author visited this particular district once. The evident depressiveness of it oppresses. 
Let's have a look on the map of the youth's (16-29 years) share in total population (Appendix 7). Our estimates reveal that this age group accumulates more than $40 \%$ of all internal movements in Russia in 2010. And let's recall that some of the relocations were obviously not recorded. The regional centers are spotlighted on this map better of all. The mean share of youths in the regional centers is $24,5 \%$, with the Russian average 19,8\% (see Table 1). We want to add that the most attractive migration centers pull the biggest part of international migration (Lee 1966; Massey, Arango 1993). Our calculations show that during the period 2003-2010 the towns of Rostov region accepted $65,4 \%$ of international migrants, the towns of Altai region even more $-72,8 \%$.

Finally, we'll have a glance at the map of the burden on the working age population (Appendix 8). Here we have the crystal picture. Migration attractive centers don't suffer from the burden because they are "nourished" by the young migrants. This indicator is very nice because it crosses out the territories which population is not far from the traditional type of reproduction. The big share of children is a burden too.

To the end of the paragraph we would like to give an example of visual analysis of the spatial differentiation of the demographic features. This analysis is possible only with the help of cartographic research method. It is known that the big attractive center form's a depressive "ring" around itself (Treyvish, Nefedova 2010). The size of the ring is proportioned to the attractive force of the center. The huge depressive ring of Moscow (diameter is about $500 \mathrm{~km}$ ) is clearly visible almost on the all maps. Smaller zones we can see around St.Petersburg (200-250 km), Ekaterinburg (150 $\mathrm{km})$, Barnaul (100-120 km), Kazan' (80-100 km). Quite predictably, the most depressive districts are placed in the area of attraction of several centers. For example the eastern parts of Kursk and Orel regions which are in the area of "migration interest" of seven (!) centers at once: Belgorod, Kursk, Orel, Tula, Ryazan', Lipetsk, Voronezh. And, on top of everything, ubiquitous Moscow. All these curious observations are possible only due to the cartographic visualization of the demographic data.

\section{Intraregional youth's migration estimation}

For the deep research on intraregional youth's spatial mobility we decided to choose several contrast regions. Our choice fell on five regions with available statistics: Altai Krai, Kostromskaya oblast', Kurskaya oblast', Rostovskaya oblast' and Bashkortostan Republic.

For the cohort research we took the ones of 1988-1992 years of birth. At the moment of the Census 2010 they were 18-22 years old. "Student" ages. All of the cohorts must have experienced the 18-years peak of migration activity during the period between the Censuses 2002 and 2010. Naturally at the moment of the Census 2002 they were 10-14 years old.

So the idea of the method is quite simple. People can live, die or move, not vanish. As we already mentioned the mortality is quite insignificant in the young ages (for proof see Table 2). So we can evaluate the migration balance by the comparison of the Censuses data considering mortality. This method is known as the method of "shifting ages". Here is the cohort research on migration.

Table 2. The discrepancy in youth's migration statistics: the Censuses and the current migration record.

\begin{tabular}{lccccc}
\hline & \multicolumn{5}{c}{ Region } \\
\cline { 2 - 6 } Cohort of 1988-1992 years of bitrh & $\begin{array}{c}\text { Altai } \\
\text { Krai }\end{array}$ & $\begin{array}{c}\text { Kostromskaya } \\
\text { oblast' }\end{array}$ & $\begin{array}{c}\text { Kurskaya } \\
\text { oblast' }\end{array}$ & $\begin{array}{c}\text { Rostovskaya } \\
\text { oblast' }\end{array}$ & $\begin{array}{c}\text { Bashkortostan } \\
\text { Republic }\end{array}$ \\
\hline Population in 2002 & 183477 & 51412 & 84398 & 297503 & 346412 \\
Population in 2010 & 172493 & 44446 & 74400 & 335303 & 324327 \\
Dead in 2003-2010 & 1617 & 430 & 587 & 1968 & 2967 \\
Change by the Censuses & -10984 & -6966 & -9998 & 37800 & -22085 \\
Registered migration in 2003-2010 & -5880 & -1435 & -583 & 1428 & -1066 \\
Discrepancy & -3487 & -5101 & -8828 & 38340 & -18052 \\
Unaccounted change, \% & $-1,9$ & $-9,9$ & $-10,5$ & 12,9 & $-5,2$ \\
\hline
\end{tabular}

Source: The Censuses 2002 and 2010, the current migration record.

The discrepancy strikes. The sources of migration statistics are incomparable. If we take the Censuses as the main source (there are more reason for such assumption), unaccounted decrease in cohort size reached 10,5\% in Kursk 
region. At the same time in the Rostov region the current migration record missed the $12,9 \%$ increase in the size of chosen cohort. Thou number of registered migrants is less than the number of dead during the period in Rostov region! (Table 7).

The scale of the research allows us to look at the inter-Census (almost precisely migration) losses of the regional periphery by every municipal district. And the picture is really horrible. Up to 70\% of the youths (cohort 1988-1992)! We can only imagine the future of the population where just $30 \%$ of the youths are willing to stay. And I bet there are not the best $30 \%$.

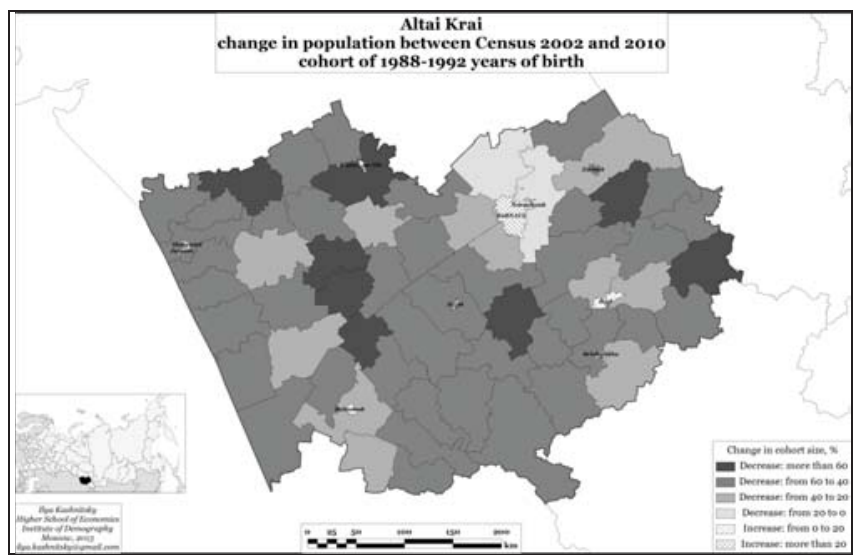

Figure 6. Change in cohort size during the period between Censuses 2002 and 2010. Altai Krai.

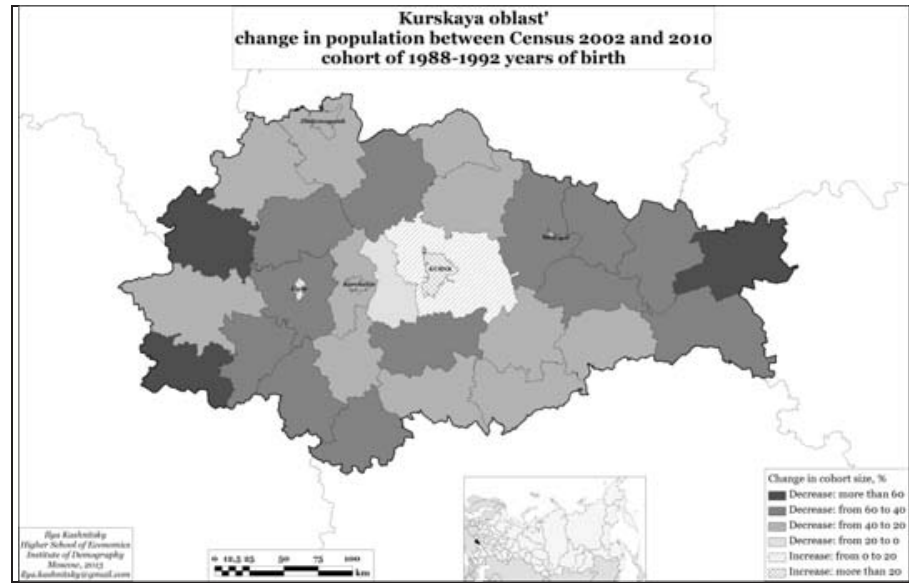

* You can see the colored maps for the whole five regions in the attachment (Appendix 9-18).

Figure 7. Change in cohort size during the period between Censuses 2002 and 2010. Kurskaya oblast'.

The maps (Figures 6, 7) show that only the big cities can attract the youths. In the case of Kursk region only the regional center is attractive enough for the young. Unfortunately, our research shows the demographic fatality of Russian hinterland.

\section{Cohort intensity of intraregional migration}

We found highly interesting to compare the cohort intensity of intraregional migration by several adjacent one-year 
cohorts (from 1988 to 1992 in our case). Using the data of current record we calculate the intensity of migration for every age of every cohort in every possible calendar year. The size of the cohorts was calculated from the Census 2002 data. We considered mortality and the balance of the external for the region migration. Then by comparing these intensities we can make some conclusions about the dynamics of intraregional youth's migration in the region.
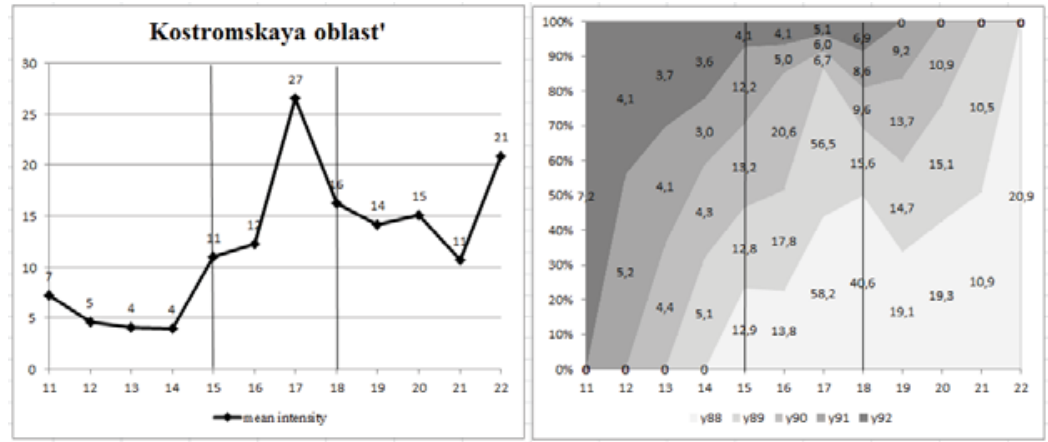

Figure 8. The intensity* of the intraregional migration of Kosrtomskaya oblast'.
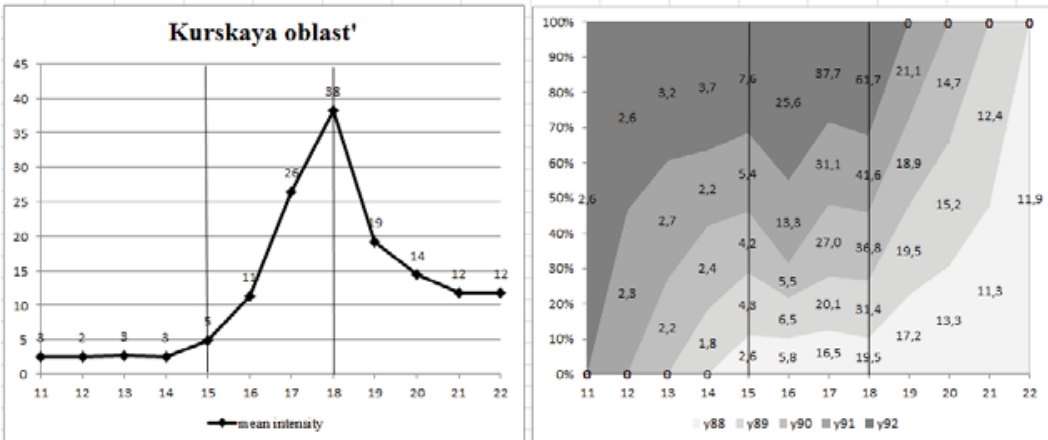

* Left: the mean value of migration intensity for 5 cohorts at the same age. Right: the shade of grey shows the relative value; the absolute value of intensity is inscribed over the diagram.

Figure 9. The intensity of the intraregional migration of Kurskaya oblast'.

The given graphics (Figures 8, 9) point out the decrease in migration intensity in Kosrtoma region and an increase in migration intensity in Kursk region. We compare only migration intensity of the adjacent one-year cohorts at the same age. Thus we can only make the full matching for the ages 15-18, because every single cohort from our choice (19881992) lived in this ages during the period 2003-2010.

The author's hypothesis states that by the means of this analysis we can roughly judge the dynamics of regional center (centers) migration attractiveness.

\section{Conclusion}

This research focuses on the way the demographic structures form under the influence of migration. In this paper we are consider mainly the internal migration (more intraregional, less interregional) as the key factor. The research is held on the level of municipal districts, which allows us to analyze the intraregional migration dynamics.

We note the increase in the intensity of the centripetal movement in the regions. The pace of the depopulation and ageing in the hinterland is accelerating. The most depressive districts have lost more than $60 \%$ of school graduates during the last inter-Census period. Migration proves to be the main factor of changes in the demographic structures. 
The remoteness of the peripheral district determines the level of its depressiveness as well as the attractive power of the center. Every big center of migration attraction forms a depressive ring around itself. This is the result of "migration exhaustion". We can see no sustainable demographic development of Russian hinterland.

At the end of the paper an author's method of estimating the dynamics in attractiveness of the regional center's is given.

\section{Acknowledgement}

The author of the paper expresses his sincere gratitude to his scientific adviser Nikita Mkrtchan.

\section{Reference}

Chudinovskikh, O. (2005). Migration Statistics in the Russian Federation: basic problems and possible solutions. Report on UNECE/UNFPA/NIDI Workshop on Migration Statistics, 24-28 January.

Coleman, D. (2006). Immigration and ethnic change in low-fertility countries: A third demographic transition. Population and Development Review, 32(3), 401-446.

Fassmann, H, Münz, R. (1992). Patterns and Trends of International Migration in Western Europe. Population and Development Review, 18(3), 457-480.

Frey, W. (1995). Immigration and Internal Migration "Flight": A California Case Study. Population and Environment, 16(4), 353-375.

Greenwood, M. (1975). Research on Internal Migration in the United States: A Survey. Journal of Economic Literature, 13(2), 397-433.

Hicks, J. (1932). The theory of wages. London: Macmillan.

Lee, E. (1966). Theory of Migration . Demography. 3(1): 47-57.

Massey, D, Arango, J et. all. (1993). Theories of International Migration. Population and Development Review, 19(3), 431-466.

Mkrtchan, N. (2012). Vliyanie Migracii na Vozrastnoi Sostav Naseleniya Gorodov i Regionov Rossii: Ocenka na Osnove Dannikh Perepisei Naseleniya 1989 i 2002 gg. (The Impact of Migration on Age Structures of Tows and Regions: an Estimate on Cunsus 1989 and 2002 Data). Regional'nie Issligovania (Regional Researches), 2(36), 66-76.

Moiseenko, V. (2004). Vnutrennyaya Migratcia Naselenia (The Internal Migration). Moscow, 285 P.

Price, D. (1948). Distance and Direction as Vectors of Internal Migration, 1935 to 1940. Social Forces, 27(1), 48-53.

Ravenstein, E. (1885) The Laws of Migration. Journal of the Royal Statistical Society, 48, 167-227.

Ravenstein, E. (1889) The Laws of Migration. Journal of the Royal Statistical Society, 52, 241-301.

Thomas, D. (1938). Research Memorandum on Migration Differentials. New York: Social Science Research Council. Bulletin 43.

Treyvish, A, Nefedova T. (2010). Goroda i Selskaya Mestnost': Sostoyanie i Sootnoshenie v Prostranstve Rossii (Towns and Country: the State and Ratio in Russian Space). Regional'nie Issligovania (Regional Researches), 2, $42-57$.

\section{Appendix (links to maps)}

\section{The whole gallery of maps (18) can be viewed and downloaded here:}

Via Google Drive https://drive.google.com/folderview?id=0B1Cid1hm5YLRRk50Q09Zd3FJX00\&usp=sharing

Via Yandex Disk http://yadi.sk/d/4RNwbvgb6NGoo

Via Dropbox https://www.dropbox.com/sh/uxp809hqos4gtyk/po1grLna-w

\section{Maps of Russia one by one (better for watching online):}

Mean age of the population, the whole population. https://www.dropbox.com/s/57s5nip4b4ye9ov/Appendix_1-Mean_age.png Median age of the population, the whole population. https://www.dropbox.com/s/k71a6qeyo1peeqb/Appendix_2-Median_age_all.png Median age of the population, male population. https://www.dropbox.com/s/n7iyv0s223yneff/Appendix_3-Median_age_male.png Median age of the population, female population. https://www.dropbox.com/s/y07p6lacqekjp2o/Appendix_4-Median_age_female.png Sex ratio, the whole population. https://www.dropbox.com/s/qibwc826izt0677/Appendix 5-Sex Ratio.png Sex ratio, young population. https://www.dropbox.com/s/zz4hstpx04anr1m/Appendix_6-Sex_Ratio_16-29.png Young population. https://www.dropbox.com/s/x8rkbmog6g8lc4p/Appendix_7-Young.png Burden on the working age population. https://www.dropbox.com/s/vhe0ammkfelrnzz/Appendix_8-Burden.png 